\title{
Study of Immune Cells Involved in the Antitumor Effect of Kefir in a Murine Breast Cancer Model
}

\author{
A. de Moreno de LeBlanc, ${ }^{\star} † \ddagger$ C. Matar, ${ }^{*}$ E. Farnworth, $\S$ and G. Perdigón $†{ }^{1}$ \\ *Départment de Chimie-Biochimie, Université de Moncton, Moncton, New Brunswick, Canada E1A 3E9 \\ †Centro de Referencia para Lactobacilos (CERELA)-Consejo Nacional de Investigaciones Científicas y Técnicas (CONICET), \\ Chacabuco 145, San Miguel de Tucumán, Tucumán, Argentina \\ ‡Cátedra de Inmunología. Facultad de Bioquimíca, Química y Farmacia, Universidad Nacional de Tucumán, San Miguel de Tucumán, \\ Tucumán, Argentina \\ §Agriculture and Agri-Food Canada, Food Research and Development Centre (FRDC), St-Hyacinthe, Quebec, Canada J2S 8E3
}

\begin{abstract}
Administration of kefir and a kefir cell-free fraction $(\mathrm{KF})$ to mice injected with breast tumor cells produced, locally in the mammary gland, different profiles of cells secreting cytokines. Here, the immune cell populations in mammary glands affected by the cyclic consumption of kefir or KF for 2 or $7 \mathrm{~d}$ were evaluated using a breast tumor model. Apoptosis was also assayed as another mechanism involved in tumor growth delay. The rate development of tumor cells, IgA(+) cells, and CD4+ and CD8+ T lymphocytes was monitored in mammary gland tissues. The number of Bcl-2(+) cells in the mammary gland was compared with the apoptosis observed in the tumor. Two-day cyclical administration of both products delayed tumor growth and increased the number of IgA(+) cells in the mammary gland. Changes in the balance between CD4+ and CD8+ cells in the mammary gland were observed in mice from the group fed $\mathrm{KF}$ cyclically for $2 \mathrm{~d}$, such that the number of CD4+ cells increased when the number of CD8+ cells remained constant. Mice that received 2-d cyclic administration of $\mathrm{KF}$ showed significant increases in the number of apoptotic cells and decreases in Bcl-2(+) cells in the mammary gland, compared with the tumor control group. The present study allows a better understanding of the mechanisms (immune and nonimmune) involved in the antitumor effect observed in mice administered kefir or KF. The importance of nonmicrobial components released during milk fermentation to obtain the beneficial antitumor effects is also reported.
\end{abstract}

Key words: kefir, breast cancer, immune response

\section{INTRODUCTION}

Lactic acid bacteria (LAB) and other probiotic organisms in fermented milks have elicited health-promoting

Received February 14, 2006.

Accepted November 28, 2006.

${ }^{1}$ Corresponding author: perdigon@cerela.org.ar biological functions in the host (Drouault and Corthier, 2001). A number of studies have noted the immunomodulatory properties of probiotic organisms, especially lactobacilli. Consumption of LAB and milks fermented by them can increase the systemic immune response (Perdigón et al., 1999, 2001) as well as local immune responses in the mucosal tissues $[\operatorname{IgA}(+)$ cells in the intestine, bronchus, and mammary gland; de Moreno de LeBlanc et al., 2005]. For these and other reasons, there has been a steady increase in the consumption of fermented dairy products (i.e., yogurt and other fermented milks) containing viable LAB.

Kefir is a fermented milk that contains a unique mixture of different microorganisms. These include the bacteria Lactobacillus parakefir, $L b$. kefir, $L b$. kefiranofaciens ssp. kefiranofaciens, Lb. kefiranofaciens ssp. kefirgranum, Lactococcus lactis ssp. lactis, Lc. lactis ssp. cremoris, Lc. lactis ssp. diacetylactis, Leuconostoc mesenteroides ssp. cremoris, and the yeasts Candida kefyr, Saccharomyces unisporus, and Sacc. turicensis (Farnworth and Mainville, 2003; Mainville et al., 2006).

In addition to LAB, fermented milks can possess other nonbacterial components produced during fermentation that contribute to immunogenicity and other beneficial properties such as antitumor activities (LeBlanc et al., 2002). Kefir and sphingomyelin isolated from the lipids in kefir have been reported to stimulate the immune system in both in vitro and in vivo studies (Furukawa et al., 1991; Osada et al., 1994; Vinderola et al., 2005).

Immunostimulation by fermented milks as a means of keeping the host immune system in a permanent state of readiness has been shown to successfully prevent different cancers (Valdéz et al., 1997; Perdigón et al., 2001). Studies have been done on the beneficial effects of fermented products, including kefir, in the prevention of different types of cancers (Furukawa et al., 1990; de Moreno de LeBlanc and Perdigón, 2004).

Breast cancer is one of the most common cancers in women, and many dietary factors are related to this 
disease, either positively or negatively. Previous studies in our laboratory showed that milk fermented by Lactobacillus helveticus R389 was able to delay tumor growth in an experimental breast cancer model using BALB/c mice (de Moreno de LeBlanc et al., 2005a). This effect was related to the immunoregulatory capacity of this fermented milk or substances released in the milk fermented by $L b$. helveticus R389, possibly peptides, because of the high proteolytic activity of this bacterial strain. Consumption of this fermented milk modulated the relationship between the immune and endocrine systems and decreased the levels of IL-6, which is very important in estrogen-dependent tumors and induced cellular apoptosis, an inhibitory mechanism limiting tumor growth.

Another important finding of this study was the demonstration that orally administered fermented milk could modify the immune cell populations in distant mucosal sites and maintain these cells in an alert state. In addition, this response was not maintained when it was not necessary; a local stimulus was necessary to produce an activation of the local immune response (de Moreno de LeBlanc et al., 2005b).

In another study conducted in our laboratory, we demonstrated the modulatory capacity of a kefir cellfree fraction (KF) on the immune response in mammary glands and tumors, by studying the immune responses, using a measurement of the cytokines involved in these sites, of mice that had received $\mathrm{KF}$ or whole kefir (de Moreno de LeBlanc et al., 2006). The previous results suggested that these products could induce changes in the immune cell populations in mammary glands related to differences in the cytokine profiles in these glands.

The aim of the present study was to analyze different infiltrative immune cell populations in the mammary gland that could be involved in the antitumor response observed in mice fed kefir or KF by using a hormonedependent breast cancer model. Activation of the immune cells and the cytokines released play a very important role in preventing tumor growth. Thus, this study identified the infiltrative immune cells and also estimated the state of this activation by measuring Bcl2 protein in addition to induction of the apoptosis mechanisms that could be involved in the antitumor effect observed with kefir consumption.

\section{MATERIALS AND METHODS}

\section{Animals and Experimental Groups}

Female BALB/c mice from Charles River Laboratories (Montreal, Quebec, Canada), weighing 19 to $21 \mathrm{~g}$, were separated into 5 experimental groups: 1) a tumor control group, in which mice received an injection with tumor cells; 2) a 2-d kefir group, in which mice were fed with whole kefir for 2 consecutive days (basal 2-d), injected with tumor cells, and then fed kefir cyclically for 2 consecutive days (5-d break from kefir administration in between) until d 27;3) a 2-d KF group, which was the same as the 2-d kefir group except that mice were fed KF instead of kefir; 4) a 7-d kefir group, in which mice were fed whole kefir for 7 consecutive days (basal 7-d), injected with tumor cells, and then fed kefir cyclically for $7 \mathrm{~d}$ (7-d kefir feeding followed by a 5 -d break); and 5) a 7-d KF group, which was the same as the 7-d kefir group except that mice were fed KF instead of kefir.

All groups contained 25 to 30 mice that received a constant-nutrient formula commercial diet (balanced/ autoclaved Rodent Diet; Charles River Laboratories, Saint-Constant, QC, Canada) and water ad libitum. Five mice $(n=5)$ from each group were killed when each sample was taken [basal sample (d 0), after 2 or $7 \mathrm{~d}$ of kefir or $\mathrm{KF}$ feeding (prior to the tumor injection), and 13,20 , or $27 \mathrm{~d}$ after tumor cell injection]. The experiments were repeated 3 times.

All experimental protocols were approved by the Animal Protection Committee of the Université de Moncton and followed the Guide for the Care and Use of Laboratory Animals of the Canadian Council on Animal Care.

\section{Kefir and Kefir Fraction}

Commercial kefir (Liberty Company, Brossard, QC, Canada), previously described by Mainville et al. (2006), was centrifuged at $2,750 \times g$ (CS 6R centrifuge, Beckman, Dallas, TX) for $20 \mathrm{~min}$ at $4^{\circ} \mathrm{C}$. The cell-free supernatant (KF) was freeze-dried (Freezone 4.5, Labco Co., Kansas City, MO) and kept refrigerated $\left(4^{\circ} \mathrm{C}\right)$ until tested. Microbial analysis of the supernatant and complete samples of fresh and freeze-dried and rehydrated kefir were previously performed by Vinderola et al. (2006), who found less than $10 \mathrm{cfu} / \mathrm{mL}$ of yeast and bacteria in the supernatant.

\section{Tumor Induction and Feeding Protocol}

The American Type Culture Collection tumoral cell line $4 \mathrm{~T} 1$ was used to induce breast tumor growth. Each mouse was challenged by a single subcutaneous injection $(0.5 \mathrm{~mL})$ of tumor cells $\left(1.4 \times 10^{4}\right.$ cells $\left./ \mathrm{mL}\right)$ in the upper right mammary gland.

The experimental groups 2-d kefir and 7-d kefir were given a standard mouse chow diet supplemented with whole kefir diluted 1:100 in sterile water, in Petri dishes, as a substitute for the drinking water for 2 or 7 consecutive days. Kefir was given diluted in this form according to the previous results, in which mice admin- 
istered this dilution showed the best intestinal immune response without microbial translocation to the visceral organs (Vinderola et al., 2005). The daily intake of kefir was $3.1 \pm 0.3 \mathrm{~mL} / \mathrm{mouse}$.

The $\mathrm{KF}$ was dissolved in distilled water to a final protein concentration of $100 \mu \mathrm{g}$ in $200 \mu \mathrm{L}$ of solution. Each mouse in the 2-d KF and 7-d KF groups was given $200 \mu \mathrm{L}$ of KF per day of feeding for the length of the feeding period. At the end of each feeding period, mice were injected with tumor cells in the same manner as the tumor control animals. Four days after tumor injection, kefir or KF was again added to the diet for 2 or 7 consecutive days, followed by a 5 -d break (no kefir or $\mathrm{KF}$ ), then were again fed kefir or $\mathrm{KF}$ for 2 or $7 \mathrm{~d}$. Feeding was given cyclically in this manner until the end of the experiment ( $27 \mathrm{~d}$ after tumor induction).

\section{Sampling Procedures}

Tumor growth was evaluated by caliper measurement of the tumor length and width. Tumor volume was calculated using the formula $\mathrm{V}=0.4 \times \mathrm{d}^{2} \times \mathrm{D}$, where $\mathrm{V}$ is the volume in milliliters, and $\mathrm{d}$ and $\mathrm{D}$ are the shortest and longest diameters, respectively, in centimeters. Samples were obtained from each group at the following times: basal sample (d 0), after 2 or $7 \mathrm{~d}$ kefir or KF feeding (prior to tumor cell injection), and at 13,20 , or $27 \mathrm{~d}$ after tumor cell injection. Mice were anesthetized intraperitoneally using a mixture of ketamine hydrocholoride (Bioniche Animal Health Canada Inc., ON, Canada), $100 \mu \mathrm{g} / \mathrm{g}$ of BW, and xylasine hydrochloride (Sigma, St. Louis, MO), $5 \mu \mathrm{g} / \mathrm{g}$ of BW. Blood samples were obtained by cardiac puncture. For the basal and 13-d post tumor cell injection samples, the entire mammary gland was removed. In subsequent samples, the tumor and mammary gland tissue without the tumor (from the same breast in which the tumor cells were injected) were removed. To obtain serum, blood was incubated at $37^{\circ} \mathrm{C}$ for $3 \mathrm{~h}$ and centrifuged at $1,000 \times g$ for $10 \mathrm{~min}$. The serum was stored at $-20^{\circ} \mathrm{C}$ until used for cytokine measurements.

\section{Immunofluorescence Assay for IgA-Secreting Cells and $C D 4+$ and $C D 8+T$ Lymphocytes}

Mammary gland tissue sections $(4 \mu \mathrm{m})$ from each group were used for the immunofluorescence assays. Tissues were prepared for histological evaluation, fixed in formaldehyde, dehydrated using a graded series of ethanol and xylene substitutes, and then embedded in paraffin.

The numbers of $\operatorname{IgA}(+)$ cells and CD4+ and CD8+ T lymphocytes were determined by direct immunofluorescence assays. To study IgA(+) cells, slides were incu- bated with $\alpha$-chain monospecific antibody conjugated with fluorescein isothiocyanate (FITC, Sigma). For determination of CD4+ and CD8+ lymphocytes, monoclonal antibodies conjugated with FITC were used (Cedarlane, Ottawa, Canada). The number of fluorescent cells was counted in 30 fields of vision, as seen with $1,000 \times$ magnification using a fluorescent light microscope. The results were expressed as cells in 10 fields of vision.

\section{Bcl-2(+) Cell Determination in Histological Sections}

Bcl-2(+) cells were detected by indirect immunofluorescence on mammary gland tissue sections following the technique described by de Moreno de LeBlanc et al. (2004). Hamster anti-mouse Bcl-2 monoclonal antibody (PharMingen, Becton Dickinson Co., Ottawa, Canada) (diluted in saponin-PBS) was applied to the tissue sections for $75 \mathrm{~min}$ at room temperature $\left(21^{\circ} \mathrm{C}\right)$. The sections were then treated with diluted rabbit anti-Syrian hamster antibody conjugated with FITC (Jackson Immuno Research Labs. Inc., West Grove, PA). The number of fluorescent cells was counted in 30 fields of vision and the results were expressed as the number of positive cells in 10 fields of vision, as seen with $1,000 \times$ magnification using a fluorescent light microscope.

\section{Apoptosis Determination}

Apoptosis was evaluated for the presence of DNA breaks detected in the paraffin cuts of breast tumor tissues using the Apoptosis Detection System, Fluorescein kit (Promega, Madison, WI). The fragmented DNA of apoptotic cells was measured by incorporation of fluorescein-12-2'-deoxyuridine $5^{\prime}$-triphosphate (dUTP) at $3^{\prime}$-OH ends of DNA using the enzyme terminal deoxynucleotidyl transferase, which forms a polymeric tail using the principle of the terminal deoxynucleotidyl transferase biotin dUTP nick-end labeling (TUNEL) assay (Gavrieli et al., 1992). The fluorescein-12-dUTP nick-end-labeled DNA was visualized directly by fluorescence microscopy. Cells were defined as apoptotic if the entire nuclear area of the cell was stained fluorescent. Apoptosis was expressed as the number of apoptotic cells in 10 fields with $1,000 \times$ magnification using a fluorescence microscope with a standard fluorescent filter.

\section{Statistical Analyses}

Statistical analyses were performed using the software package Minitab 14 (Minitab, Inc., State College, PA) by ANOVA GLM followed by a Tukey's posthoc test, and $P<0.05$ was considered significant. Unless 
otherwise indicated, all values $(n=15)$ were the means of 3 independent trials (no significant differences were observed between individual replicates) \pm standard deviation.

\section{RESULTS AND DISCUSSION}

Different cytokine profiles were reported for mice injected with the breast tumor cells that received 2 or 7 $\mathrm{d}$ of cyclical administration of kefir or KF. This result suggests that oral administration of this fermented product or its cell-free fraction induced the activation of different cells in mammary glands compared with those activated only for tumor injection (de Moreno de LeBlanc et al., 2006).

Both B and T cells can migrate from Peyer's patches found in the small intestine to the respiratory, gastrointestinal, and genitourinary tract, as well as to exocrine glands such as the lacrimal, salivary, mammary, and prostatic glands (Brandtzaeg and Pabst, 2004). Orally administered LAB can increase the number of $\operatorname{IgA}(+)$ cells not only in the intestine, but also in other distant mucosal sites such as the bronchus and mammary gland. Immunoglobulin $\mathrm{A}(+)$ cells in the mammary gland from mice that received milk fermented with $L b$. helveticus $\mathrm{R} 389$ were studied because this product was previously shown to delay breast tumor growth in mice (de Moreno de LeBlanc et al., 2005b). Lactobacillus helveticus-fermented milk increased the levels of $\operatorname{IgA}(+)$ in mammary glands only when a local stimulus (tumor cell injection) was presented. In the present work, IgA(+) cells and T lymphocytes were studied in the mammary gland of mice that had been injected with the tumor cells and that received kefir or KF.

\section{$\operatorname{IgA}(+)$ Cells in the Mammary Gland}

Immunoglobulin $\mathrm{A}(+)$ cell numbers did not vary in mice injected with the tumor cell line (tumor control group) during the study (Figure 1). Throughout the study, mice receiving 7-d cyclical kefir or KF maintained the number of $\operatorname{IgA}(+)$ cells, similar to the tumor control group. Mice from the 2-d KF and 2-d kefir groups showed significant increases in the number of $\operatorname{IgA}(+)$ cells in the sample taken $20 \mathrm{~d}$ after tumor injection (22 \pm 5 and $19 \pm 4$ for the 2-d kefir and 2-d KF group, respectively) compared with the tumor control group (12 \pm 3$)$.

Two days of cyclical administration of kefir or KF produced increases in the number of $\operatorname{IgA}(+)$ cells in the mammary gland after tumor injection; however, an increase was not observed in animals fed fermented milk that did not receive tumor injection (data not shown), demonstrating that the enhancement of $\operatorname{IgA}(+)$ cells in the mammary gland requires a stronger stimulus such as that induced by tumor cells. The biological role of $\operatorname{IgA}(+)$ cells in response to mammary tumor development is not well understood. It could be suggested that these cells might be able to bind toxic metabolites produced during tumor development.

\section{CD4+ and CD8+ T Lymphocytes in Mammary Glands Injected with Tumor Cells}

Study of the T lymphocyte population is important, because tumor antigens recognized by $\mathrm{T}$ cells are the principal targets for protective antitumor immunity, especially in solid tumors. CD8+ cytotoxic T lymphocytes can carry out a surveillance function, recognizing and killing potentially malignant cells. Although $\mathrm{T}$ helper CD4+ cells are not generally cytotoxic, in the presence of tumors they can play an important role in cytokine release ( $\mathrm{such}$ as release of $\mathrm{IFN} \gamma$ ), thus regulating the immune response (Read and Powrie, 2001; Belardelli and Ferrantini, 2002; Curotto de Lafaille and Lafaille, 2002).

When $\mathrm{T}$ cells were studied in our model, it was possible to observe changes in the balance between CD4+ and CD8+ cells in the mammary gland of mice fed cyclically with $\mathrm{KF}$ for $2 \mathrm{~d}$ and injected with tumor cells. The mice showed increases in the number of CD4+ cells, whereas the CD8+ cell number remained constant (Figure $2 \mathrm{~A}$ and $2 \mathrm{~B}$ ). This was different from the tumor control group, which maintained a balance of these cells in the mammary glands toward CD8+ cells rather than CD4+ cells. An increase of CD8+ T lymphocytes was observed after tumor cell injection (tumor control group), compared with the basal data $(14 \pm 2)$ but the number of CD4+ T lymphocytes remained constant throughout the experimental period. Mice that received whole kefir showed increases only in $\operatorname{IgA}(+)$ cells, but the number of CD4+ cells did not show the same increases as observed in mice that received the KF. This last observation confirms the importance of the immunomodulating properties of the nonmicrobial substances contained in the fermented product (de Moreno de LeBlanc et al., 2005b).

The results obtained for CD4+ and CD8+ T cell populations agree with a colon cancer model in which mice injected with 1,2-dimethylhydrazine and fed yogurt had inhibited tumor development. In mice fed yogurt, the balance of CD4+ and CD8+ cells favored the first population and differed from that of the 1,2-dimethylhydrazine control animals, which had increased cytotoxic cells (Perdigón et al., 2002). In the same model in mice given yogurt without carcinogen, the number of CD4+ or CD8+ T lymphocytes did not increase, compared with 


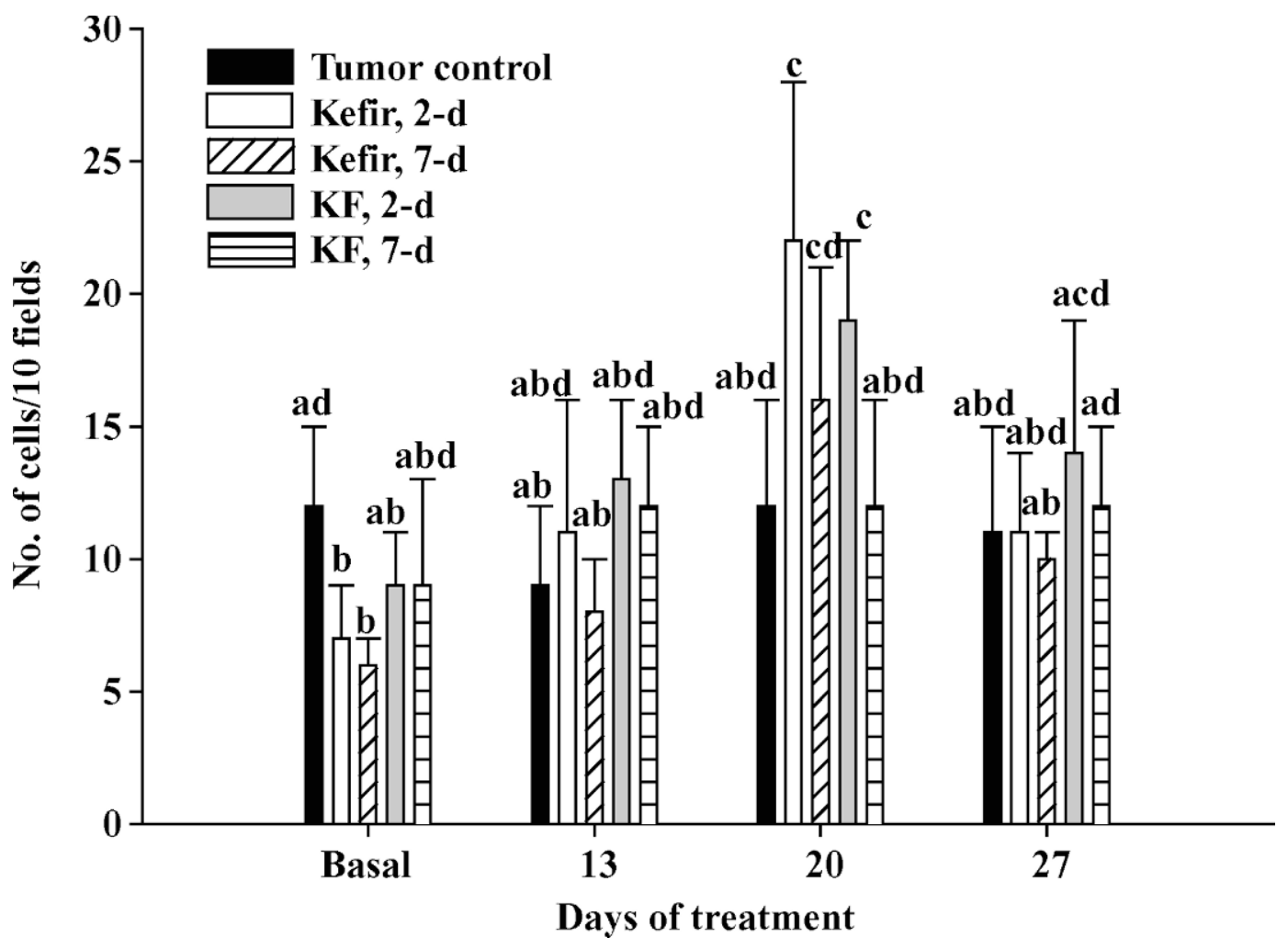

Figure 1. Effect of tumor injection, kefir, and kefir cell-free fraction $(\mathrm{KF})$ on $\operatorname{IgA}(+)$ cells in the mammary gland. Positive cells were counted in histological sections from mammary glands of the tumor control, 2-d kefir, 7-d kefir, 2-d KF, and 7-d KF groups. Data correspond to the average $\pm \mathrm{SD}$ of the results of 15 animals from 3 separate experiments. ${ }^{\mathrm{a}-\mathrm{d}}$ Means for each bar without a common letter differ significantly $(P<0.05)$.

nontreatment controls (de Moreno de LeBlanc et al., 2004; de Moreno de LeBlanc and Perdigón, 2005).

\section{Tumor Growth and Apoptosis Determination}

The tumors became visible and palpable after approximately $12 \mathrm{~d}$. de Moreno de LeBlanc et al. (2006) reported previously that 2-d cyclical administration of whole kefir delayed tumor development, compared with the control group. The same cyclical feeding with $\mathrm{KF}$ showed a significant decrease in tumor volume compared with all the other groups. Mice receiving a 7$\mathrm{d}$ cyclical feeding of either kefir or KF did not show significant differences in tumor volume, compared with the tumor control group.

The mechanisms of apoptosis (or programmed cell death) in the inhibition of tumor progression are well documented (Butler et al., 1999). Apoptosis is a complex and active cellular process in which individual cells are triggered to undergo self-destruction in a manner that will neither injure neighboring cells nor elicit an inflammatory reaction. The balance between cell proliferation and cell death is important to maintain the equi- librium in different tissues, and a disturbance in this balance may lead to tumor development (Hao et al., 1998). Many pathways have been reported by which it is possible to induce cell death by apoptosis, and one mechanism used for tumor cells is to avoid these pathways, causing uncontrolled growth (Sellers and Fisher, 1999).

Considering that cytokines such as tumor necrosis factor- $\alpha$ could be involved in certain apoptotic pathways (Sellers and Fisher, 1999) and an enhancement of this cytokine was observed in the basal sample obtained from mice that received 2-d cyclic KF (the group in which the tumor volume was significantly lower than the other groups; de Moreno de LeBlanc et al., 2006), apoptosis induction was studied in relation to tumor growth (Table 1). Mice that received 2-d cyclic administration of KF showed significant increases in the number of apoptotic cells in the 3 samples assayed, compared with those in the tumor control group. Mice given a 2-d cyclic diet supplemented with whole kefir showed increased cellular apoptosis in the tumor $20 \mathrm{~d}$ after tumor injection. Afterward, the number of apoptotic cells presented by this group was statistically similar 
A

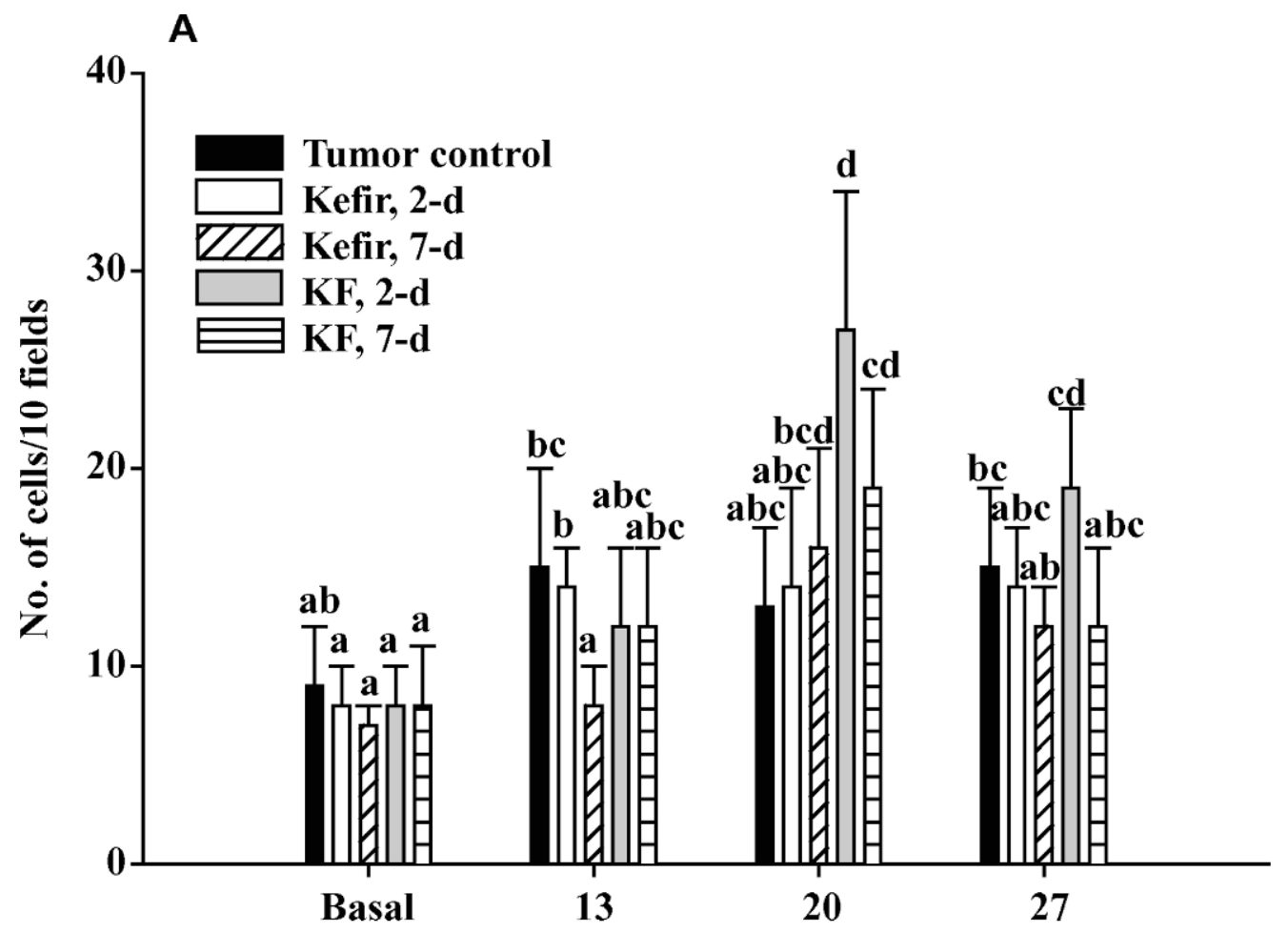

B

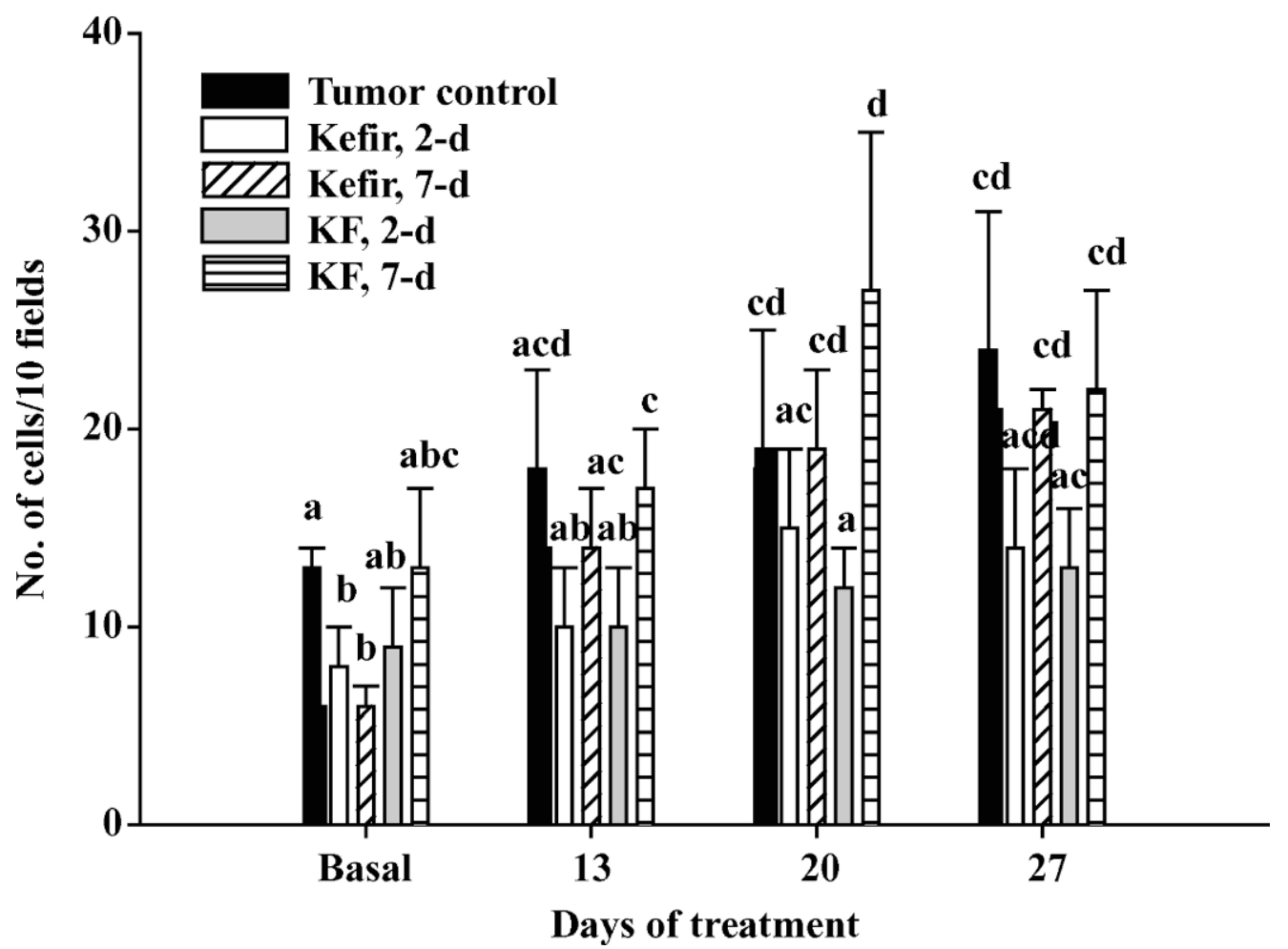

Figure 2. CD4+ and CD8+ T lymphocytes in mammary glands from mice injected with tumor cells and administered kefir or kefir cellfree fraction (KF). CD4+ (A) or CD8+ (B) cells were counted in histological sections from mammary glands of the tumor control, 2-d kefir, 7-d kefir, 2-d KF, and 7-d KF groups. Data correspond to the average \pm SD of the results of 15 animals from 3 separate experiments. ${ }^{\mathrm{a}-\mathrm{d}}$ Means for each bar without a common letter differ significantly $(P<0.05)$. 
Table 1. Study of the cellular apoptosis in the tumor tissue ${ }^{1}$

\begin{tabular}{|c|c|c|c|c|c|c|}
\hline \multirow{2}{*}{$\begin{array}{l}\text { Experimental } \\
\text { group }^{2}\end{array}$} & \multicolumn{3}{|c|}{ Tumor volume, $\mathrm{cm}^{3}$} & \multicolumn{3}{|c|}{ Number of apoptotic cells } \\
\hline & $13 \mathrm{~d}$ & $20 \mathrm{~d}$ & $27 \mathrm{~d}$ & $13 \mathrm{~d}$ & $20 \mathrm{~d}$ & $27 \mathrm{~d}$ \\
\hline $\mathrm{TC}$ & $0.02 \pm 0.01$ & $0.08 \pm 0.02^{\mathrm{a}}$ & $0.56 \pm 0.15^{\mathrm{a}}$ & $8 \pm 2^{\mathrm{a}}$ & $15 \pm 7^{\mathrm{ab}}$ & $12 \pm 8^{\mathrm{ab}}$ \\
\hline Kefir & & & & & & \\
\hline $\begin{array}{l}2-d \\
7-d\end{array}$ & $0.01 \pm 0.01$ & $\begin{array}{l}0.03 \pm 0.02^{\mathrm{b}} \\
0.07+0.03^{\mathrm{a}}\end{array}$ & $\begin{array}{l}0.25 \pm 0.06^{\mathrm{b}} \\
0.47+0.15^{\mathrm{a}}\end{array}$ & $\begin{array}{l}22 \pm 3^{\mathrm{bc}} \\
10+3^{\mathrm{a}}\end{array}$ & $\begin{array}{l}31 \pm 8^{\text {cd }} \\
19+3^{b}\end{array}$ & $\begin{array}{l}22 \pm 4^{\mathrm{b}} \\
20 \pm 6^{\mathrm{b}}\end{array}$ \\
\hline $\mathrm{KF}$ & & & & & & \\
\hline $2-d$ & $0.01 \pm 0.01$ & $0.02 \pm 0.01^{\mathrm{b}}$ & $0.15 \pm 0.02^{\mathrm{c}}$ & $31 \pm 8^{\text {cd }}$ & $42 \pm 8^{\mathrm{d}}$ & $58 \pm 3^{\mathrm{e}}$ \\
\hline 7-d & $0.02 \pm 0.01$ & $0.20 \pm 0.09^{c}$ & $0.52 \pm 0.16^{\mathrm{a}}$ & $24 \pm 8^{b c}$ & $19 \pm 6^{\mathrm{ab}}$ & $23 \pm 9^{\mathrm{ab}}$ \\
\hline
\end{tabular}

${ }^{a-e}$ Means for each value (volume or apoptotic cell number) without a common letter differ significantly $(P<0.05)$.

${ }^{1}$ Tumor volume results are expressed as means of the volume $\left(\mathrm{cm}^{3}\right)$ of the tumor \pm SD for each group. Apoptotic cells were counted in tumor tissue sections and are expressed as average \pm SD of the number of apoptotic cells counted in 10 fields at 1,000× magnification (cells/10 fields).

${ }^{2} \mathrm{TC}=$ tumor control; $\mathrm{KF}=$ kefir cell-free fraction

to that of other groups (7-d kefir and 7-d KF groups) in which the tumor grew similar to the control. This last observation could be related to the significant difference $(P<0.05)$ in tumor volume observed between the 2-d KF group and 2-d kefir group in the last sample, which was not observed in the other samples (Table 1).
Level of Bcl-2 protein is a measure of cell survival because of its antiapoptotic activity (Sellers and Fisher, 1999), which can be used to stimulate the growth of tumor cells. The increase in cellular apoptosis in mice from the groups fed kefir or KF led us to study the Bcl2 protein. Significant differences between the groups

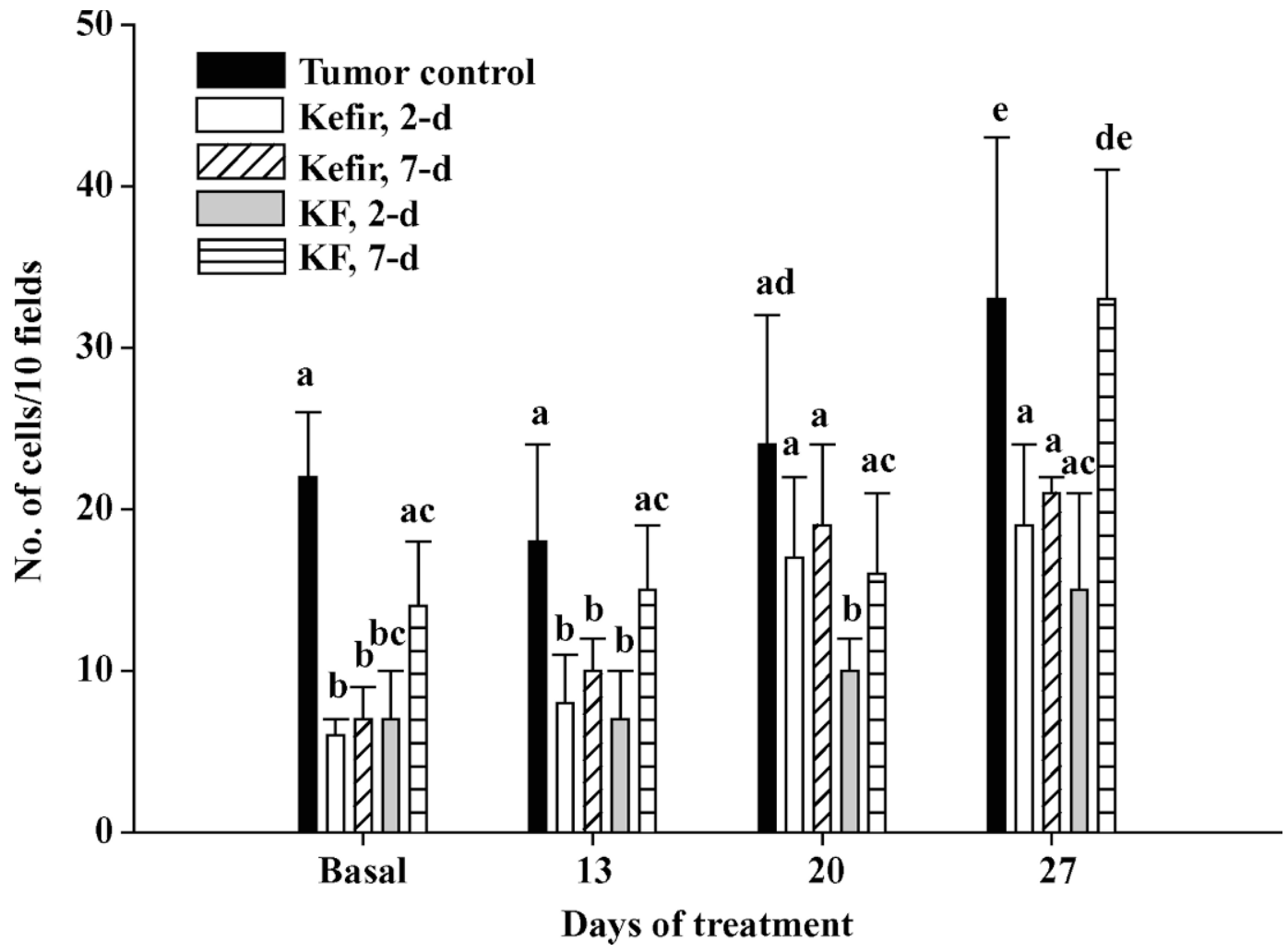

Figure 3. Bcl-2(+) cells in mammary gland tissues from mice injected with tumor cells and administered kefir or kefir cell-free fraction $(\mathrm{KF})$. Positive cells for Bcl-2 protein were counted in histological sections from mammary glands of the tumor control, 2-d kefir, 7-d kefir, 2-d KF, and 7-d KF groups. Data correspond to the average \pm SD of the results of 15 animals from 3 separate experiments. ${ }^{\text {a-e }}$ Means for each bar without a common letter differ significantly $(P<0.05)$. 
were not observed when Bcl-2(+) cells were studied in tumor tissues (data not shown), but differences were seen when this protein was studied in the mammary gland in which tumor cells were injected and the tumor grew. Bcl-2(+) cells increased significantly $(P<0.05)$ in the last sample for the tumor control group, compared with the basal sample for the same group (33 \pm 5 and $22 \pm 4$ at $d 27$ and in the basal sample, respectively; Figure 3). Mice from the 7-d KF group showed numbers of $\mathrm{Bcl}-2(+)$ cells similar to the tumor control group throughout the experiment. Mice given KF cyclically for $2 \mathrm{~d}$ had significantly $(P<0.05)$ decreased numbers of Bcl-2(+) cells in the mammary gland compared with the tumor control group in all samples assayed (Figure 3 ). The results presented above show a correlation between increased apoptosis of the tumor tissues and decreases in the Bcl-2 protein in cells in the respective mammary glands. The Bcl-2 pathway was one of the mechanisms involved in the survival of cells in the mammary gland in which the tumor grew fastest, and the induction of this antiapoptotic pathway was avoided with the 2-d cyclic administration of KF. This administration induced the activation of apoptotic mechanisms in the tumor, which resulted in a tumor volume lower than in the other groups.

\section{CONCLUSIONS}

The present study allows a better understanding of the mechanisms involved in the antitumor effect observed in mice administered kefir or KF. The importance of an adequately balanced local immune response in the mammary glands to avoid tumor growth was shown. The importance of nonmicrobial components released during milk fermentation and the period of administration needed to obtain beneficial antitumor effects was also reported. Other mechanisms related to estrogen synthesis in the mammary gland could also be involved in the effect observed with kefir administration.

\section{ACKNOWLEDGMENTS}

The authors thank Jairo Duarte for his help with animal care and sampling. This work was financially supported by the Atlantic Innovation Fund and Natural Sciences and Engineering Council of Canada; Agriculture and Agri-Food Canada, Food Research and Development Centre (St-Hyacinthe, QC, Canada); and CONICET (Consejo Nacional de Investigaciones Científicas y Técnicas) PIP-5445, Argentina.

\section{REFERENCES}

Belardelli, F., and M. Ferrantini. 2002. Cytokines as a link between innate and adaptive antitumor immunity. Trends Immunol. 23:201-208.
Brandtzaeg, P., and R. Pabst. 2004. Let's go mucosal: Communication on slippery ground. Trends Immunol. 25:570-577.

Butler, L. M., P. J. Hewett, R. A. Fitridge, and P. A. Cowled. 1999. Deregulation of apoptosis in colorectal carcinoma: Theoretical and therapeutic implications. Aust. N. Z. J. Surg. 69:88-94.

Curotto de Lafaille, M. A., and J. J. Lafaille. 2002. CD4+ regulatory $\mathrm{T}$ cells in autoimmunity and allergy. Curr. Opin. Immunol. 14:771-778.

de Moreno de LeBlanc, A., C. Maldonado Galdeano, S. Chaves, and G. Perdigón. 2005. Oral administration of $L$. casei CRL 431 increases immunity in bronchus and mammary glands. Eur. J. Inflamm. $3: 25-30$.

de Moreno de LeBlanc, A., C. Matar, E. Farnworth, and G. Perdigon. 2006. Study of cytokines involved in the prevention of a murine experimental breast cancer by kefir. Cytokine 34:1-8.

de Moreno de LeBlanc, A., C. Matar, N. LeBlanc, and G. Perdigon. 2005a. Effects of milk fermented by Lactobacillus helveticus R389 on a murine breast cancer model. Breast Cancer Res. 7:477-486.

de Moreno de LeBlanc, A., C. Matar, C. Thériault, and G. Perdigon. 2005b. Effects of milk fermented by Lactobacillus helveticus R389 on immune cells associated to mammary glands in normal and a breast cancer model. Immunobiology 210:349-358.

de Moreno de LeBlanc. A., and G. Perdigón. 2005. Antitumor activity of yoghurt. Pages 115-140 in Focus on Colorectal Cancer Research. J. D. Martinez, ed. Nova Science Publishers, Hauppauge, NY.

de Moreno de LeBlanc, A., and G. Perdigón. 2004. Yoghurt feeding inhibits promotion and progression of experimental colorectal cancer. Med. Sci. Monit. 10:96-104.

de Moreno de LeBlanc, A., J. Valdéz, and G. Perdigón. 2004. Regulatory effect of yoghurt on intestinal inflammatory immune response. Eur. J. Inflamm. 2:21-61.

Drouault, S., and G. Corthier. 2001. Health effects of lactic acid bacteria ingested in fermented milk. Vet. Res. 32:101-117.

Farnworth, E. R., and I. Mainville. 2003. Kefir: A fermented milk product. Pages 77-111 in Handbook of Fermented Functional Foods. E. R. Farnworth, ed. CRC Press, Boca Raton, FL.

Furukawa, N., A. Matsuoka, T. Takahashi, and Y. Yamanaka. 1991. Effects of fermented milk on the delayed-type hypersensitivity response and survival in mice bearing Meth-A. Anim. Sci. Technol. 62:579-585.

Furukawa, N., A. Matsuoka, T. Takahashi, and Y. Yamanaka. 1990. Effects of orally administered yogurt and kefir on tumor growth in mice. J. Jpn. Soc. Nutr. Food Sci. 43:450-453.

Gavrieli, Y., Y. Sherman, and S. A. Ben-Sasson. 1992. Identification of programmed cell death in situ via specific labeling of nuclear DNA fragmentation. J. Cell Biol. 119:493-501.

Hao, X., M. Du, A. Bishop, and I. Talbot. 1998. Imbalance between proliferation and apoptosis in the development of colorectal carcinoma. Virchows Arch. 433:523-527.

LeBlanc, J. G., C. Matar, J. C. Valdez, J. LeBlanc, and G. Perdigón. 2002. Immunomodulatory effects of peptidic fractions issued from milk fermented with Lactobacillus helveticus. J. Dairy Sci. 85:2733-2742.

Mainville, I., N. Robert, B. Lee, and E. R. Farnworth. 2006. Polyphasic characterization of the lactic acid bacteria in kefir. Syst. Appl. Microbiol. 29:59-68.

Osada, K., K. Nagira, K. Teruya, H. Tachibana, S. Shirahata, and H. Murakami. 1994. Enhancement of interferon- $\beta$ production with sphingomyelin from fermented milk. Biotherapy 7:115-123.

Perdigón, G., A. de Moreno de LeBlanc, J. Valdez, and M. Rachid. 2002. Role of yoghurt in the prevention of colon cancer. Eur. J. Clin. Nutr. 56:S65-S68.

Perdigón, G., R. Fuller, and R. Raya. 2001. Lactic acid bacteria and their effect on the immune system. Curr. Issues Intest. Microbiol. $2: 27-42$.

Perdigón, G., E. Vintini, S. Alvarez, M. Medina, and M. Medici. 1999. Study of the possible mechanisms involved in the mucosal immune system activation by lactic acid bacteria. J. Dairy Sci. 82:1108-1114. 
Read, S., and F. Powrie. 2001. CD4(+) regulatory T cells. Curr. Opin. Immunol. 13:644-649.

Sellers, W. R., and D. E. Fisher. 1999. Apoptosis and cancer drug targeting. J. Clin. Invest. 104:1655-1661.

Valdéz, J. C., M. Rachid, E. Bru, and G. Perdigón. 1997. The effect of yoghurt on the cytotoxic and phagocytic activity of macrophages in tumor-bearing mice. Food Agric. Immunol. 9:299-308.
Vinderola, C. G., J. Duarte, D. Thangavel, G. Perdigón, E. Farnworth, and C. Matar. 2005. Immunomodulating capacity of kefir. J. Dairy Res. 72:195-202.

Vinderola, C. G., G. Perdigón, J. Duarte, E. Farnworth, and C. Matar. 2006. Effects of the oral administration of the products derived from milk fermentation by kefir microflora on immune stimulation. J. Dairy Res. 73:472-479. 